\title{
A novel bi-directional promoter system allows tunable recombinant protein production in Pichia pastoris
}

Vignesh Rajamanickam ${ }^{1,2+}$, Karl Metzger $^{1 \dagger}$, Christian Schmid $^{3}$ and Oliver Spadiut ${ }^{* *}$ (1)

\begin{abstract}
Background: The methylotrophic yeast Pichia pastoris is a well-studied host organism for recombinant protein production, which is usually regulated either by a constitutive promoter (e.g. promoter of glyceraldehyde-3-phosphate dehydrogenase; $P_{G A P}$ ) or an inducible promoter (e.g. promoter of alcohol oxidase $1 ; P_{A O X_{1}}$ ). Both promoter systems have several advantages and disadvantages; with one of the main disadvantages being their lack of tunability. Various novel promoter systems, which are either inducible or de-repressed, allowing higher degrees of freedom, have been reported. Recently, bi-directional promoter systems in P. pastoris with two promoter systems regulating recombinant expression of one or more genes were developed. In this study, we introduce a novel bi-directional promoter system combining a modified catalase promoter system ( $\mathrm{P}_{\mathrm{DC}}$; derepressible and inducible) and the traditional $\mathrm{P}_{\mathrm{AOX} 1}$, allowing tunable recombinant protein production.

Results: We characterized a recombinant P. pastoris strain, carrying the novel bi-directional promoter system, during growth and production in three dynamic bioreactor cultivations. We cloned the model enzyme cellobiohydralase downstream of either promoter and applied different feeding strategies to determine the physiological boundaries of the strain. We succeeded in demonstrating tunability of recombinant protein production solely in response to the different feeding strategies and identified a mixed feed regime allowing highest productivity.

Conclusion: In this feasibility study, we present the first controlled bioreactor experiments with a recombinant $P$. pastoris strain carrying a novel bi-directional promotor combination of a catalase promoter variant $\left(\mathrm{P}_{\mathrm{DC}}\right)$ and the traditional $\mathrm{P}_{\mathrm{AOX} 1}$. We demonstrated that this bi-directional promoter system allows tunable recombinant protein expression only in response to the available $\mathrm{C}$-sources. This bi-directional promoter system offers a high degree of freedom for bioprocess design and development, making bi-directional promoters in P. pastoris highly attractive for recombinant protein production.
\end{abstract}

Keywords: Pichia pastoris, Bi-directional promoter, Bioprocess development, Mixed feed, Tunable recombinant protein production

\section{Background}

The methylotrophic yeast Komagataella phaffii, also known as Pichia pastoris, is extensively used as host

\footnotetext{
*Correspondence: oliver.spadiut@tuwien.ac.at

'Vignesh Rajamanickam and Karl Metzger contributed equally to this work

${ }^{1}$ Research Division Biochemical Engineering, Institute of Chemical, Environmental and Biological Engineering, TU Wien, Gumpendorfer Strasse 1a, 1060 Vienna, Austria

Full list of author information is available at the end of the article
}

organism for recombinant protein production (e.g. [17]). The main advantages of $P$. pastoris are its fast growth, its ability to use the cheap substrate methanol as sole carbon source, its ability to perform typical eukaryotic post-translational modifications and the possibility of secreting the recombinant product $[5,6,8-10]$. Usually, recombinant protein production in $P$. pastoris is either regulated by a constitutive promoter, like the promoter of glyceraldehyde-3-phosphate dehydrogenase $\left(\mathrm{P}_{\mathrm{GAP}}\right)$, or an inducible promoter, like the promoter of alcohol oxidase 
$1\left(\mathrm{P}_{\mathrm{AOX} 1}\right)$ (e.g. $\left.[7,8,11,12]\right)$. Both of these prominent promoter systems are characterized by several advantages, but also disadvantages.

The strong, constitutive $\mathrm{P}_{\mathrm{GAP}}$ allows high product yields in rather short process times [13]. However, cell growth and recombinant protein production are directly linked causing a high metabolic burden for the cells, which might lead to the production of unwanted metabolites or even cell death [14].

On the other hand, biomass formation can be decoupled from recombinant protein production using the inducible $\mathrm{P}_{\mathrm{AOX} 1}$, which is tightly regulated and gives high expression levels $[12,13,15,16]$. However, the safety aspect for industrial large-scale manufacturing processes with $\mathrm{P}_{\mathrm{AOX} 1} 1^{-d r i v e n} P$. pastoris production strains needs particular attention, as the storage of large volumes of hazardous, flammable methanol is highly undesirable. Apart from the fact that methanol makes the fermentation process dangerous and environmentally non-friendly, methanol metabolism leads to great heat evolution and high oxygen consumption, which pose additional challenges for cultivations at large scales.

Furthermore, a common disadvantage of both promoter systems $\mathrm{P}_{\mathrm{GAP}}$ and $\mathrm{P}_{\mathrm{AOX} 1}$ is the lack of tunability. It would be highly advantageous to be able to adjust recombinant protein production to different growth conditions and environmental stress to reduce metabolic burden and thus the formation of unwanted metabolites. Besides, it would be highly advantageous to have an expression system in yeast where two recombinant genes can be controlled, regulated and tuned separately. Potential applications of such a system include the balanced co-expression of the individual peptide chains of dimeric proteins, or the consecutive expression of a chaperone followed by the tailored expression of the target product to boost the yield of correctly folded and active product (Fig. 1). Recently, we have used such a system for the recombinant production of the enzyme horseradish peroxidase [17]. However, such a tunable, bi-directional promoter system is not possible using a combination of the promoter systems $\mathrm{P}_{\mathrm{GAP}}$ and $\mathrm{P}_{\mathrm{AOX} 1}$ due to the aforementioned disadvantages. Thus, a lot of effort is ongoing to identify and investigate novel promoter systems, which are either inducible or de-repressed under limiting conditions [12, 18-26].

In this study, we introduce a novel modified catalase promoter system $\left(\mathrm{P}_{\mathrm{DC}}\right)$, which is a $500 \mathrm{bp}$ fragment of the DNA upstream of the peroxisomal catalase gene, active under both limiting conditions and by induction, allowing a high degree of freedom in its regulation and tunability. Furthermore, we present our results with respect to the characterization of a novel bi-directional promoter system, where we combined this novel $P_{D C}$ variant and $\mathrm{P}_{\mathrm{AOX} 1}$ in a bi-directional manner. In this feasibility study, we cloned two gene variants of the model enzyme cellobiohydrolase 2 ( $\mathrm{CBH} 2)$ downstream of either promoter to demonstrate the proof-of-concept that the expression level of this product can solely be tuned by induction conditions using the bi-directional promoter system. We used the same product downstream of the two promoters to exclude the possibility that different products are differently well expressed due to product-specific features, not only affecting productivity but also strain physiology. Thus, we ensured that the effects on productivity and physiology only resulted from induction conditions and the consequent regulation of the two promoters and not from productspecific features. In summary, our results nicely demonstrate tunability of a novel bi-directional promoter system solely in response to cultivation conditions, which widens the toolbox for P. pastoris. A potential future application of this system could be the subsequent production a chaperone and a target protein, as schematically shown in Fig. 1.
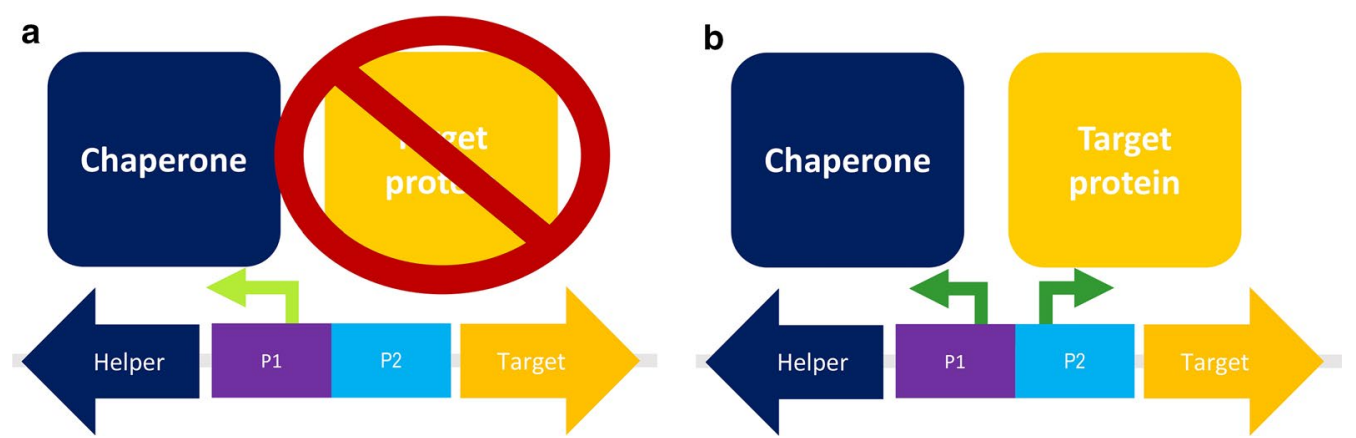

Fig. 1 A bi-directional promoter system, where both promoters can be controlled and tuned separately allows $\mathbf{a}$ the consecutive and $\mathbf{b}$ the concomitant production of a chaperone and a target protein 


\section{Methods}

\section{Host organism and model protein}

A $P$. pastoris BSYBG11 strain harbouring a novel bidirectional promoter system, comprising the modified derepressible and inducible $\mathrm{P}_{\mathrm{DC}}$ and the methanol inducible $\mathrm{P}_{\mathrm{AOX} 1}$, was constructed by Bisy e.U. (Hofstaetten/ Raab, Austria). BSYBG11 is a killer-plasmid-free next generation platform strain, based on the NRLY 11430 wildtype strain, where the AOX1 gene was deleted according to Sturmberger et al. [27]. The lignocellulolytic enzyme $\mathrm{CBH} 2$ derived from Trichoderma reesei [28] was used as a model protein in this study and cloned downstream of either promoter. Furthermore, the strain carried a Zeocin resistance gene, and the pre-pro signal sequence of the alpha-mating factor allowed product secretion.

\section{Bioreactor cultivations}

All bioreactor cultivations were carried out in a $5 \mathrm{~L}$ lab scale glass bioreactor (Infors, Switzerland). Monitoring and control of process parameters was done by the Lucullus process information management system (PIMS; Biospectra, Switzerland). $\mathrm{pH}$ was controlled at $\mathrm{pH} 5.0$ and temperature at $30{ }^{\circ} \mathrm{C}$. The dissolved oxygen concentration $\left(\mathrm{dO}_{2}\right)$ was kept above $30 \%$ with a cascaded control of agitation and addition of pure oxygen.

Strain specific physiological parameters, such as substrate uptake rates $\left(\mathrm{q}_{\mathrm{s}}\right)$ and biomass yields $\left(\mathrm{Y}_{\mathrm{X} / \mathrm{S}}\right)$, are prerequisites for designing efficient fed-batch strategies. Thus, dynamic cultivations with shifts in $\mathrm{q}_{\mathrm{s}}$ and repeated substrate pulses were done to evaluate these strain specific physiological parameters, according to our previous studies (e.g. [29-32]). Based thereon, mixed feed cultivations were carried out to analyze tunability of recombinant protein production. A summary of the three dynamic cultivations performed in this study and their respective goals is shown in Table 1 .

Prior to all cultivations, precultures were prepared with frozen cryo-stocks in yeast nitrogen base medium (YNB) supplemented with Zeocin. The preculture was incubated at $30{ }^{\circ} \mathrm{C}$ and $230 \mathrm{rpm}$ overnight. The batch phase for all cultivations was started by adding the preculture to the bioreactor $[10 \%(\mathrm{v} / \mathrm{v})]$. After the batch, different feeding strategies were applied (Table 1). All cultivations were carried out in twofold basal salt medium (BSM) with a final glycerol concentration of $60 \mathrm{~g} \mathrm{~L}^{-1}$ in the batch medium. Samples were taken throughout the cultivations for offline analyses. In all the cultivations, the feed rate (FR) was calculated from biomass $\left(c_{x}\right)$ and substrate $\left(c_{s}\right)$ concentrations, volume of the bioreactor $\left(V_{R}\right)$ and specific substrate uptake rates $\left(\mathrm{q}_{\mathrm{s}}\right)$ and controlled using a feed forward strategy (Eq. 1).

$$
\mathrm{FR}_{\mathrm{t}}=\frac{\mathrm{c}_{\mathrm{X}} \cdot \mathrm{V}_{\mathrm{R}}}{\mathrm{c}_{\mathrm{S}}} \cdot \mathrm{q}_{\mathrm{S}}
$$

\section{Offline data analysis}

Biomass concentration was determined by optical density measurements at $600 \mathrm{~nm}$ and dry cell weight measurement, as described before (e.g. [29-32]). Protein concentration was measured at $595 \mathrm{~nm}$ by the Bradford assay using the Sigma-Aldrich protein assay kit with bovine serum albumin as standard in the range of $0.2-1.2 \mathrm{mg} \mathrm{mL} \mathrm{m}^{-1}$. The specific productivity $\left(\mathrm{q}_{\mathrm{p}}\right)$ was determined from the total extracellular protein concentration measured in the cell-free cultivation broth and the respective dry cell weight. Product formation and electrophoretic purity was checked by SDS-PAGE.

\section{Results and discussion}

In this study, a recombinant $P$. pastoris strain harbouring a novel bi-directional promoter system with the two promoters $\mathrm{P}_{\mathrm{DC}} / \mathrm{P}_{\mathrm{AOX} 1}$ was characterized and analyzed for tunable recombinant production of the model enzyme $\mathrm{CBH} 2$. The goal of this proof-of-concept study was to show that expression can be stirred solely by induction conditions using this novel bi-directional system, which is why we used the same model product to exclude product-dependent variations in productivity as well as product-dependent effects on physiology. We performed three dynamic bioreactor cultivations to characterize the recombinant $P$. pastoris strain (Table 1$)$. In all of these cultivations we determined a maximum specific growth rate $\left(\mu_{\max }\right)$ on glycerol of $0.27 \mathrm{~h}^{-1}$, a $\mathrm{q}_{\mathrm{s}, \text { max,gly }}$ of $0.57 \mathrm{~g} \mathrm{~g}^{-1} \mathrm{~h}^{-1}$ and a biomass yield $\left(\mathrm{Y}_{\mathrm{X} / \mathrm{S}}\right)$ on glycerol of $0.47 \mathrm{~g} \mathrm{~g}^{-1}$. These values compare well with values we found for a Mut ${ }^{\mathrm{S}}$ benchmark strain before [33], indicating that the introduced genetic construct had no negative impact on the physiology of the P. pastoris strain.

\section{Fed-batch 1 (FB1)}

In the first dynamic fed-batch, we determined strain specific physiological parameters and characterized the recombinant expression profile at different process parameters (Table 1). After complete consumption of glycerol in the batch phase, we stepwise decreased $\mathrm{q}_{\mathrm{s}, \mathrm{gly}}$ in the subsequent fed-batch to find $q_{s, g l y}$ where the $P_{D C}$ promoter was fully active. We determined the specific productivity $\left(\mathrm{q}_{\mathrm{p}}\right)$ as a measure for promoter activity. As shown in Table 2 , the $\mathrm{P}_{\mathrm{DC}}$ promoter was actually never repressed, not even at high $\mathrm{q}_{\mathrm{s}, \mathrm{gly}}$. However, we found an optimum in $\mathrm{q}_{\mathrm{p}}$ at a $\mathrm{q}_{\mathrm{s}, \mathrm{gly}}$ of $0.28 \mathrm{~g} \mathrm{~g}^{-1} \mathrm{~h}^{-1}$. At lower $\mathrm{q}_{\mathrm{s}, \mathrm{gly}}, \mathrm{q}_{\mathrm{p}}$ decreased again, as the cells came close to their maintenance metabolism, which was also visible in the specific yields (Table 2). Closing C-balances underlined 


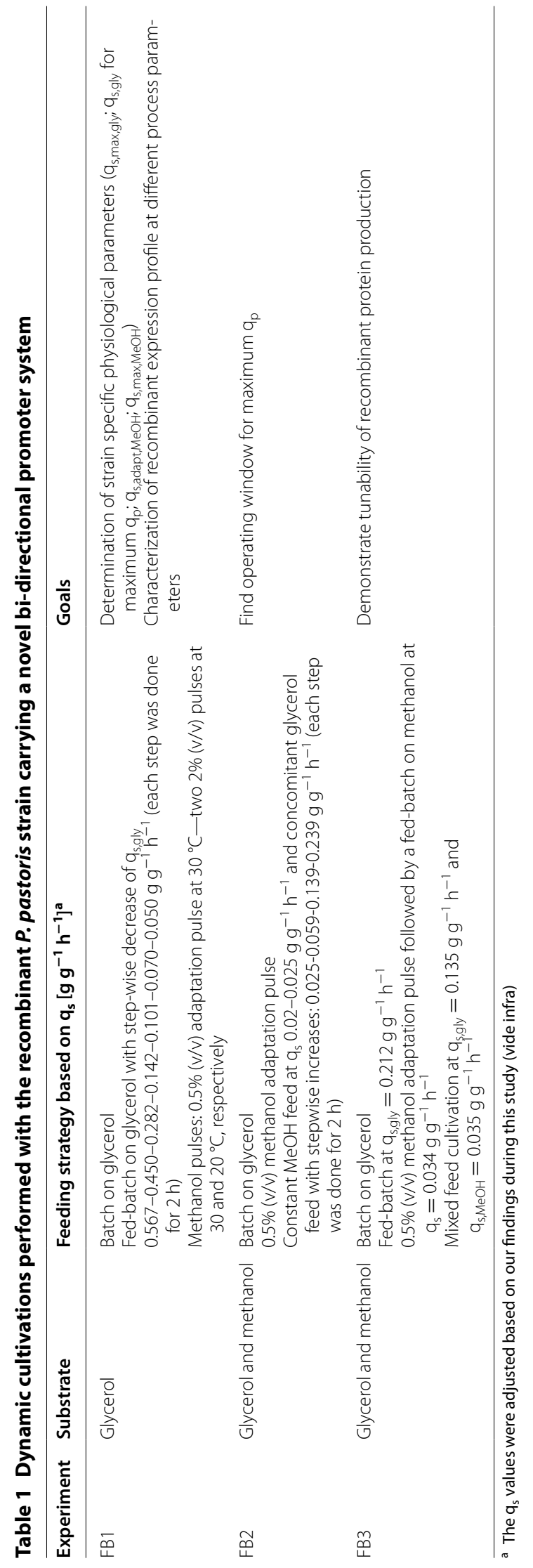


Table 2 Dynamic glycerol fed-batch phase to characterize the $P_{D C}$ in FB 1

\begin{tabular}{|c|c|c|c|c|c|c|}
\hline Steps & $q_{s, g l y}\left(g^{-1} h^{-1}\right)$ & $\mu\left(h^{-1}\right)$ & $q_{p}\left(\mathrm{mg} \mathrm{g}^{-1} h^{-1}\right)$ & $\mathrm{Y}_{\mathrm{CO}_{2} / \mathrm{S}}\left(\mathrm{Cmol} \mathrm{Cmol}^{-1}\right)$ & $\mathrm{Y}_{\mathrm{x} / \mathrm{s}}\left(\mathrm{Cmol} \mathrm{Cmol}^{-1}\right)$ & C-balance (-) \\
\hline 1 & 0.567 & 0.318 & 0.307 & 0.28 & 0.67 & 0.95 \\
\hline 2 & 0.450 & 0.251 & 0.362 & 0.34 & 0.67 & 1.01 \\
\hline 3 & 0.282 & 0.132 & 0.492 & 0.37 & 0.56 & 0.92 \\
\hline 4 & 0.142 & 0.068 & 0.349 & 0.44 & 0.51 & 0.95 \\
\hline 5 & 0.101 & 0.056 & 0.124 & 0.46 & 0.47 & 0.93 \\
\hline 6 & 0.070 & 0.039 & 0.121 & 0.51 & 0.43 & 0.94 \\
\hline 7 & 0.050 & 0.023 & 0.073 & 0.58 & 0.37 & 0.95 \\
\hline
\end{tabular}

the validity of the calculated physiological strain specific parameters.

After the dynamic glycerol phase in FB1, we added a $0.5 \%(\mathrm{v} / \mathrm{v})$ methanol adaptation pulse, followed by two $2 \%$ (v/v) pulses at each 30 and $20{ }^{\circ} \mathrm{C}$, respectively, to analyze the adaptation characteristics to methanol and determine the specific uptake rate of methanol $\left(\mathrm{q}_{\mathrm{s}, \mathrm{MeOH}}\right)$ as well as $\mathrm{q}_{\mathrm{p}}$ at both temperatures (Table 3).

The adaptation time, which is the time taken for adaptation of the culture to the new substrate methanol [29, 30], of the strain carrying the bi-directional promoter system to methanol at $30{ }^{\circ} \mathrm{C}$ was only $3 \mathrm{~h}$, which was much lower compared to a $\mathrm{Mut}^{\mathrm{S}}$ benchmark strain, where we had found adaptation times of more than $6 \mathrm{~h}$ $[29,33]$. This drastic reduction might be due to the concomitant presence of two promoters, which are inducible by methanol.

As shown in Table 3, the specific uptake rate of methanol was higher at $20{ }^{\circ} \mathrm{C}$ than at $30{ }^{\circ} \mathrm{C}$. However, $\mathrm{q}_{\mathrm{p}}$ was higher at $30{ }^{\circ} \mathrm{C}$, which is why we chose this temperature for the subsequent fed-batch phases on methanol.

Table 3 Methanol pulses at 30 and $20^{\circ} \mathrm{C}$, respectively, to characterize the $P_{D C}$ in FB1

\begin{tabular}{|c|c|c|}
\hline Phases & $q_{s, M e O H}\left(g^{-1} h^{-1}\right)$ & $q_{p}\left(m g g^{-1} h^{-1}\right)$ \\
\hline 0.5\% adapt & 0.011 & 0.021 \\
\hline $2 \% \mathrm{MeOH}_{\mathrm{T}=30^{\circ} \mathrm{C}}$ & 0.035 & 0.115 \\
\hline $2 \% \mathrm{MeOH}_{\mathrm{T}=20^{\circ} \mathrm{C}}$ & 0.039 & 0.056 \\
\hline
\end{tabular}

\section{Fed-batch 2 (FB2)}

In FB2, we adapted one of our previous mixed feed strategies to allow fast physiological strain characterisation as well as bioprocess development in a mixed feed environment [34]. We constantly fed methanol at a $\mathrm{q}_{\mathrm{s}}=0.022-$ $0.025 \mathrm{~g} \mathrm{~g}^{-1} \mathrm{~h}^{-1}$, corresponding to around $75-80 \%$ of $\mathrm{q}_{\mathrm{s}, \mathrm{max}, \mathrm{MeOH}}$ at $30{ }^{\circ} \mathrm{C}$ (Table 3 ), and concomitantly fed glycerol, which we stepwise increased (Table 1). In the different phases, we determined specific rates and yields, to demonstrate tunability of the system and to find a good operating window allowing highest $\mathrm{q}_{\mathrm{p}}$ (Table 4). Again, closing $\mathrm{C}$-balances underlined the validity of the calculated strain specific parameters.

As shown in Table $4, \mathrm{q}_{\mathrm{p}}$ could be tuned by adjusting different $\mathrm{q}_{\mathrm{s}}$ ratios. Interestingly, the highest $\mathrm{q}_{\mathrm{p}}$ was achieved in the presence of methanol at a rather low $\mathrm{q}_{\mathrm{s}, \mathrm{gly}}$. Compared to the $\mathrm{q}_{\mathrm{p}}$ at a similar $\mathrm{q}_{\mathrm{s}, \mathrm{gly}}$ in FB1, which was $0.073 \mathrm{mg} \mathrm{g}^{-1} \mathrm{~h}^{-1}$ at $\mathrm{q}_{\mathrm{s}, \mathrm{gly}}=0.050 \mathrm{~g} \mathrm{~g}^{-1} \mathrm{~h}^{-1}$, we obtained a more than fivefold higher $q_{p}$ of $0.372 \mathrm{mg} \mathrm{g}^{-1} \mathrm{~h}^{-1}$ at $\mathrm{q}_{\mathrm{s}, \mathrm{gly}}=0.059 \mathrm{~g} \mathrm{~g}^{-1} \mathrm{~h}^{-1}$ in the presence of methanol. Furthermore, we found a 1.5-fold higher $\mathrm{q}_{\mathrm{p}}$ of $0.115 \mathrm{mg} \mathrm{g}^{-1} \mathrm{~h}^{-1}$ compared to the sole presence of methanol (Table 3). Increasing $\mathrm{q}_{\mathrm{s}, \mathrm{gly}}$ in the presence of methanol had a negative impact on $\mathrm{q}_{\mathrm{p}}$, which we ascribe to repression effects, as reported in similar studies before [34]. Offline analysis confirmed no accumulation of methanol in the mixed-feed phase.

\section{Fed-batch 3 (FB3)}

In the final cultivation (FB3), we demonstrated tunability of recombinant protein production by adjusting different

Table 4 Dynamics in FB2 to analyze tunability and to find an operating window for the bi-directional promoter system allowing highest $q_{p}$

\begin{tabular}{|c|c|c|c|c|c|c|c|}
\hline Steps & $q_{s, g l y}\left(g^{-1} h^{-1}\right)$ & $q_{s, \mathrm{MeOH}}\left(\mathbf{g ~ g}^{-1} h^{-1}\right)$ & $\mu\left(h^{-1}\right)$ & $q_{p}\left(m g g^{-1} h^{-1}\right)$ & $\mathrm{Y}_{\mathrm{CO}_{2} / \mathrm{S}}\left(\mathrm{Cmol} \mathrm{Cmol}^{-1}\right)$ & $\mathrm{Y}_{\mathrm{X} / \mathrm{s}}\left(\mathrm{Cmol} \mathrm{Cmol}^{-1}\right)$ & C-balance (-) \\
\hline 1 & 0.025 & 0.022 & 0.005 & 0.109 & 0.78 & 0.14 & 0.92 \\
\hline 2 & 0.059 & 0.024 & 0.009 & 0.372 & 0.71 & 0.23 & 0.94 \\
\hline 3 & 0.139 & 0.025 & 0.031 & 0.349 & 0.55 & 0.42 & 0.97 \\
\hline 4 & 0.239 & 0.023 & 0.112 & 0.099 & 0.42 & 0.57 & 0.99 \\
\hline
\end{tabular}


Table 5 Strain specific, physiological parameters determined in FB3

\begin{tabular}{|c|c|c|c|c|c|c|c|}
\hline Phase & $q_{s, g l y}\left(g^{-1} h^{-1}\right)$ & $q_{s, M e O H}\left(g^{-1} h^{-1}\right)$ & $\mu\left(h^{-1}\right)$ & $q_{p}\left(\mathrm{mg} \mathrm{g}^{-1} h^{-1}\right)$ & $\mathrm{Y}_{\mathrm{CO}_{2} / \mathrm{s}}\left(\mathrm{Cmol} \mathrm{Cmol}^{-1}\right)$ & $\mathrm{Y}_{\mathrm{x} / \mathrm{s}}\left(\mathrm{Cmol} \mathrm{Cmol}^{-1}\right)$ & C-balance (-) \\
\hline Glycerol & 0.212 & - & 0.122 & 0.368 & 0.40 & 0.57 & 0.97 \\
\hline Methanol & - & 0.034 & 0.003 & 0.097 & 0.83 & 0.15 & 0.98 \\
\hline Mixed feed & 0.135 & 0.035 & 0.106 & 0.573 & 0.54 & 0.41 & 0.95 \\
\hline
\end{tabular}

feeding regimes. We analyzed productivity as well as the the strain specific, physiological parameters on glycerol, on methanol as well as in a mixed feed environment (Table 1). The results are summarized in Table 5.

The $\mathrm{q}_{\mathrm{p}}$ in the glycerol fed-batch phase was comparable to the results we obtained in FB1 (Table 1). At a $\mathrm{q}_{\mathrm{s}, \mathrm{gly}}=0.212 \mathrm{~g} \mathrm{~g}^{-1} \mathrm{~h}^{-1}$ we calculated a $\mathrm{q}_{\mathrm{p}}=0.368 \mathrm{mg} \mathrm{g}^{-1} \mathrm{~h}^{-1}$. In the subsequent fed-batch phase on methanol, where we adjusted a $\mathrm{q}_{\mathrm{s}, \mathrm{MeOH}}=0.034 \mathrm{~g} \mathrm{~g}^{-1} \mathrm{~h}^{-1}$, which was close to $\mathrm{q}_{\mathrm{s}, \max , \mathrm{MeOH}}$, we calculated a $\mathrm{q}_{\mathrm{p}}$ of $0.097 \mathrm{mg} \mathrm{g}^{-1} \mathrm{~h}^{-1}$. When we concomitantly fed glycerol at a $\mathrm{q}_{\mathrm{s}, \mathrm{gly}}=0.135 \mathrm{~g} \mathrm{~g}^{-1} \mathrm{~h}^{-1}$, we were able to boost $\mathrm{q}_{\mathrm{p}}$ to $0.573 \mathrm{mg} \mathrm{g}^{-1} \mathrm{~h}^{-1}$, which was the highest value we obtained in all the experiments performed in this study. This value was higher than the $\mathrm{q}_{\mathrm{p}}$ we achieved in the mixed feed environment at $\mathrm{q}_{\mathrm{s}, \mathrm{gly}}=0.139 \mathrm{~g} \mathrm{~g}^{-1} \mathrm{~h}^{-1}$ in FB2, probably due to a higher $\mathrm{q}_{\mathrm{s}, \mathrm{MeOH}}$. Again, no methanol accumulation was identified during this cultivation. Closing $\mathrm{C}$-balances underlined the validity of the calculated strain specific parameters. We analyzed the cell-free cultivation broth at different time points of the cultivation on SDS-PAGE gels. As shown in Fig. 2, the main protein fraction in the cell-free cultivation broth constituted for the recombinant product CHB2, which is why it was legitimate to use the total extracellular protein content to calculate productivities.

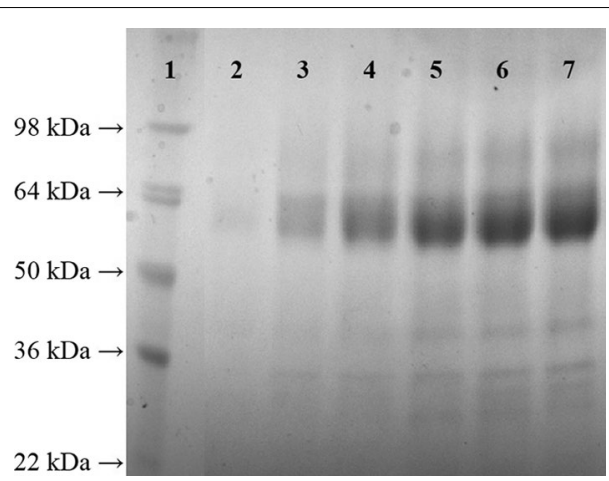

Fig. 2 SDS-PAGE gel of cell-free cultivation broth taken at different time points during FB3. Lane 1, protein ladder; lane 2, sample after batch on glycerol; lanes 3-5, samples during fed-batch at $\mathrm{q}_{\mathrm{s}, \mathrm{gly}}=0.212 \mathrm{~g} \mathrm{~g}^{-1} \mathrm{~h}^{-1}$ (samples were taken every $2 \mathrm{~h}$ ); lane 6, sample after methanol fed-batch; lane 7, sample after mixed feed phase. Size $\mathrm{CBH} 2=\mathrm{ca} .60 \mathrm{kDa}$

\section{Conclusions}

In this study we present the first controlled bioreactor experiments with a novel bi-directional promotor combination of a catalase promoter variant $\left(\mathrm{P}_{\mathrm{DC}}\right)$, which shows high activity in the presence of glycerol, but is also inducible by methanol, and the traditional $\mathrm{P}_{\mathrm{AOX} 1}$. By performing dynamic bioreactor cultivations, we physiologically characterized the recombinant strain and determined conditions allowing high productivity of the strain in only three experiments. Finally, we demonstrated that this bi-directional promoter system allows tunable recombinant protein expression solely in response to the available $\mathrm{C}$-sources. This bi-directional promoter system offers a high degree of freedom for bioprocess design and development making bi-directional promoters in $P$. pastoris highly attractive for recombinant protein production.

\begin{abstract}
Abbreviations
$\mathrm{CBH}$ 2: cellobiohydrolase 2; $q_{p}$ : strain specific productivity $\left[\mathrm{mg} \mathrm{g}^{-1} \mathrm{~h}^{-1}\right.$; $\mathrm{q}_{\mathrm{s}}$ : strain specific substrate uptake rate $\left[\mathrm{g} \mathrm{g}^{-1} \mathrm{~h}^{-1}\right] ; \mathrm{P}_{\mathrm{DC}}$ : catalase promoter variant; $P_{A O X 1}$ : alcohol oxidase promoter; $P_{G A P}$ : glyceraldehyde-3-phosphate dehydrogenase promoter; PIMS: process information management system; $\mathrm{dO}_{2}$ : dissolved oxygen concentration [\%]; $\mathrm{Y}_{\mathrm{X} / \mathrm{s}}$ : yield of biomass per substrate $\left[\mathrm{Cmol} \mathrm{Cmol}^{-1}\right]$; YNB: yeast nitrogen base; BSM: basal salt media; $\mathrm{F}_{\mathrm{R}}$ : feed rate $\left[\mathrm{L} \mathrm{h}^{-1}\right] ; \mathrm{C}_{\mathrm{S}}$ : concentration of substrate $\left[\mathrm{g} \mathrm{L}^{-1}\right] ; \mathrm{C}_{\mathrm{X}}$ : biomass concentration $\left[\mathrm{g} \mathrm{L}^{-1}\right] ; V_{\mathrm{R}}$ : volume of the reactor $[\mathrm{L}] ; \mathrm{Y}_{\mathrm{CO}_{2} / \mathrm{s}}$ : yield of carbon dioxide per substrate $\left[\mathrm{Cmol} \mathrm{Cmol}^{-1}\right]$.
\end{abstract}

\section{Authors' contributions}

KM and VR conducted the experiments. CS generated the Pichia pastoris strain. OS planned and supervised the study and wrote the paper. All authors read and approved the final manuscript.

\section{Author details}

${ }^{1}$ Research Division Biochemical Engineering, Institute of Chemical, Environmental and Biological Engineering, TU Wien, Gumpendorfer Strasse 1a, 1060 Vienna, Austria. ${ }^{2}$ Christian Doppler Laboratory for Mechanistic and Physiological Methods for Improved Bioprocesses, Institute of Chemical, Environmental and Biological Engineering, TU Wien, Vienna, Austria. ${ }^{3}$ bisy e.U., Wetzawinkel 20A, 8200 Hofstaetten/Raab, Austria.

\section{Acknowledgements}

The authors acknowledge the TU Wien University Library for financial support through its Open Access Funding Programme.

\section{Competing interests}

Bisy has an interest to commercialize bidirectional promoters.

Availability of data and materials

All data generated or analysed during this study are included in this published article. 


\section{Consent for publication}

Not applicable.

\section{Ethics approval and consent to participate}

Not applicable.

\section{Funding}

This work was financially supported by the Steirische Wirtschaftsförderungsgesellschaft and the program "Ideenreich".

\section{Publisher's Note}

Springer Nature remains neutral with regard to jurisdictional claims in published maps and institutional affiliations.

Received: 21 June 2017 Accepted: 8 September 2017

Published online: 13 September 2017

\section{References}

1. Macauley-Patrick S, Fazenda ML, McNeil B, Harvey LM. Heterologous protein production using the Pichia pastoris expression system. Yeast. 2005;22:249-70

2. Weinacker D, Rabert C, Zepeda AB, Fiqueroa CA, Pessoa A, Farias JG. Applications of recombinant Pichia pastoris in the healthcare industry. Braz J Microbiol. 2013:44:1043-8.

3. Spohner SC, Muller H, Quitmann H, Czermak P. Expression of enzymes for the usage in food and feed industry with Pichia pastoris. J Biotechnol. 2015;202:118-34

4. Cregg JM. Pichia protocols. 2nd ed. In: Cregg JM, editor. Methods in molecular biology. Totowa, NJ, US; 2007. p. 268

5. Cregg JM, Cereghino JL, Shi JY, Higgins DR. Recombinant protein expression in Pichia pastoris. Mol Biotechnol. 2000;16:23-52.

6. Cereghino JL, Cregg JM. Heterologous protein expression in the methylotrophic yeast Pichia pastoris. FEMS Microbiol Rev. 2000;24:45-66.

7. Cereghino GPL, Cereghino JL, Ilgen C, Cregg JM. Production of recombinant proteins in fermenter cultures of the yeast Pichia pastoris. Curr Opin Biotechnol. 2002;13:329-32.

8. Daly R, Hearn MT. Expression of heterologous proteins in Pichia pastoris: a useful experimental tool in protein engineering and production. J Mo Recognit. 2005;18:119-38

9. Daly R, Hearn MT. Expression of the human activin type I and II receptor extracellular domains in Pichia pastoris. Protein Expr Purif. 2006;46:456-67.

10. Spadiut O, Herwig C. Dynamics in bioprocess development for Pichia pastoris. Bioengineered. 2014;5:401-4.

11. Zhang WH, Potter KJH, Plantz BA, Schlegel VL, Smith LA, Meagher MM Pichia pastoris fermentation with mixed-feeds of glycerol and methanol: growth kinetics and production improvement. J Ind Microbiol Biotechnol. 2003:30:210-5.

12. Zhang AL, Luo JX, Zhang TY, Pan YW, Tan YH, Fu CY, Tu FZ. Recent advances on the GAP promoter derived expression system of Pichia pastoris. Mol Biol Rep. 2009;36:1611-9.

13. Cos O, Ramon R, Montesinos JL, Valero F. Operational strategies, monitoring and control of heterologous protein production in the methylotrophic yeast Pichia pastoris under different promoters: a review. Microb Cell Factories. 2006;5:17

14. Nocon J, Steiger M, Mairinger T, Hohlweg J, Russmayer H, Hann S, Gasser B, Mattanovich D. Increasing pentose phosphate pathway flux enhances recombinant protein production in Pichia pastoris. Appl Microbiol Biotechnol. 2016;100:5955-63.

15. Looser V, Bruhlmann B, Bumbak F, Stenger C, Costa M, Camattari A, Fotiadis D, Kovar K. Cultivation strategies to enhance productivity of Pichia pastoris: a review. Biotechnol Adv. 2015;33:1177-93.
16. Mochizuki S, Hamato N, Hirose M, Miyano K, Ohtani W, Kameyama S, Kuwae S, Tokuyama T, Ohi H. Expression and characterization of recombinant human antithrombin III in Pichia pastoris. Protein Expr Purif. 2001;23:55-65

17. Krainer FW, Gerstmann MA, Darnhofer B, Birner-Gruenberger R, Glieder A. Biotechnological advances towards an enhanced peroxidase production in Pichia pastoris. J Biotechnol. 2016;233:181-9.

18. Shen SG, Sulter G, Jeffries TW, Cregg JM. A strong nitrogen source-regulated promoter for controlled expression of foreign genes in the yeast Pichia pastoris. Gene. 1998;216:93-102.

19. Resina D, Serrano A, Valero F, Ferrer P. Expression of a Rhizopus oryzae lipase in Pichia pastoris under control of the nitrogen source-regulated formaldehyde dehydrogenase promoter. J Biotechnol. 2004;109:103-13.

20. Menendez J, Valdes I, Cabrera N. The ICL1 gene of Pichia pastoris, transcriptional regulation and use of its promoter. Yeast. 2003;20:1097-108.

21. Liu B, Zhang Y, Zhang X, Yan C, Zhang Y, Xu X, Zhang W. Discovery of a rhamnose utilization pathway and rhamnose-inducible promoters in Pichia pastoris. Sci Rep. 2016:6:27352.

22. Byrne B. Pichia pastoris as an expression host for membrane protein structural biology. Curr Opin Struct Biol. 2015:32:9-17.

23. Prielhofer R, Maurer M, Klein J, Wenger J, Kiziak C, Gasser B, Mattanovich D. Induction without methanol: novel regulated promoters enable highlevel expression in Pichia pastoris. Microb Cell Factories. 2013;12:5.

24. Vogl T, Glieder A. Regulation of Pichia pastoris promoters and its consequences for protein production. New Biotechnol. 2013;30:385-404

25. Vogl T, Ruth C, Pitzer J, Kickenweiz T, Glieder A. Synthetic core promoters for Pichia pastoris. ACS Synth Biol. 2014;3:188-91.

26. Vogl T, Sturmberger L, Kickenweiz T, Wasmayer R, Schmid C, Hatzl AM, Gerstmann MA, Pitzer J, Wagner M, Thallinger GG, et al. A toolbox of diverse promoters related to methanol utilization: functionally verified parts for heterologous pathway expression in Pichia pastoris. ACS Synth Biol. 2016;5:172-86.

27. Sturmberger L, Chappell T, Geier M, Krainer F, Day KJ, Vide U, Trstenjak S, Schiefer A, Richardson T, Soriaga L, et al. Refined Pichia pastoris reference genome sequence. J Biotechnol. 2016;235:121-31.

28. Brady SK, Sreelatha S, Feng Y, Chundawat SP, Lang MJ. Cellobiohydrolase 1 from Trichoderma reesei degrades cellulose in single cellobiose steps. Nat Commun. 2015:6:10149.

29. Dietzsch C, Spadiut O, Herwig C. A fast approach to determine a fed batch feeding profile for recombinant Pichia pastoris strains. Microb Cell Factories. 2011;10:85.

30. Dietzsch C, Spadiut O, Herwig C. A dynamic method based on the specific substrate uptake rate to set up a feeding strategy for Pichia pastoris. Microb Cell Factories. 2011:10:14.

31. Spadiut O, Dietzsch C, Herwig C. Determination of a dynamic feeding strategy for recombinant Pichia pastoris strains. Methods Mol Biol. 2014;1152:185-94

32. Spadiut O, Zalai D, Dietzsch C, Herwig C. Quantitative comparison of dynamic physiological feeding profiles for recombinant protein production with Pichia pastoris. Bioprocess Biosyst Eng. 2013. doi:10.1007/ s00449-013-1087-z

33. Krainer FW, Gmeiner C, Neutsch L, Windwarder M, Pletzenauer R, Herwig C, Altmann F, Glieder A, Spadiut O. Knockout of an endogenous mannosyltransferase increases the homogeneity of glycoproteins produced in Pichia pastoris. Sci Rep. 2013:3:3279.

34. Zalai D, Dietzsch C, Herwig C, Spadiut O. A dynamic fed batch strategy for a Pichia pastoris mixed feed system to increase process understanding. Biotechnol Prog. 2012. doi:10.1002/btpr.1551. 